ISSN 0854-9818

High quality planting stock - has research made a difference?

\author{
Francis S.P. $\mathrm{Ng}$
}

CENTER FOR INTERNATIONAL FORESTRY RESEARCH office address: Jalan Gunung Batu 5, Bogor 16001 Indonesia mailing address: P.O.Box 6596, JKPWB, Jakarta 10065 Indonesia tel.: +62(251) 34-3652 fax: +62(251) 32-6433

email: cifor@cgnet.com 
Acknowledgement:

This paper is reproduced from:

Yapa, A.C., ed. 1996. Proc. Intl. Symp. Recent Advances in Tropical Tree Seed Technol. and Planting Stock Production. ASEAN Forest Tree Seed Centre, Muak-Lek, Saraburi, Thailand.

\section{The CGIAR System}

The Consultative Group on International Agricultural Research (CGIAR) is an informal association of 41 public and private sector donors that supports a network of sixteen international agricultural research institutes, CIFOR being the newest of these. The Group was established in 1971. The CGIAR Centers are part of a global agricultural research system which endeavour to apply international scientific capacity to solution of the problems of the world's disadvantaged people.

\section{CIFOR}

CIFOR was established under the CGIAR system in response to global concerns about the social, environmental and economic consequences of loss and degradation of forests. It operates through a series of highly decentralised partnerships with key institutions and/or individuals throughout the developing and industrialised worlds. The nature and duration of these partnerships are determined by the specific research problems being addressed. This research agenda is under constant review and is subject to change as the partners recognise new opportunities and problems. 


\title{
High quality planting stock - has research made a difference?
}

\author{
Francis S. P. Ng \\ Research Support and Information Services, Center for International Forestry Research (CIFOR), \\ Jalan Gunung Batu 5, Bogor 16001, Indonesia
}

\begin{abstract}
$\mathbf{T}$ hirty years of research on plantingstock in Malaysia, coveting the period of a FAO/UNDP pine project, an enrichment planting effort with dipterocarps in natural forest and a compensantory plantation project with fast growing trees, had minimal effect on the course of events. The pine project and the enrichment planting project were both given up after about 75 years of effort and the compensatory plantation project is likely to end in the same way. The interface between research and application was more complicated than what managers and scientists were prepared for and the benefit of research were seldom realized.
\end{abstract}

\section{Introduction}

$\mathrm{W}$ hen I was invited to speak at this symposium I had very mixed feelings, because I cannot say from my own experience in Malaysia that planting stock research was able to positively influence timber production. I think I am qualified to make this assessment because I was closely associated with all aspects of planting stock research at the Forest Research Institute Malaysia (FRIM) from 1964 to 1990, and a large proportion of my own research was devoted to seed morphology and germination ( $\mathrm{Ng} \mathrm{1991,1992),}$

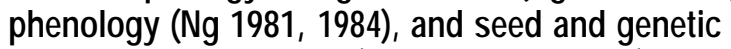
resources management ( $\mathrm{Ng} 1974,1980,1985)$. Looking back, it appears to me that the interface between research and application was far more complicated than what our scientists were prepared for. As a result, the benefits of research were seldom realized. Nevertheless, it was an intense learning period for us, and I hope this review will be useful in highlighting the nature of the problem.

The period 1960-1990 started with the replacement of British by Malaysian scientific staff at FRIM. The process was completed in 1965 when the Institute had a total of 11 inexperienced local scientists including myself. After 1965, the FAO and UNDP stepped in with a pilot project to establish pine plantations and a number of well-known scientists were brought in from overseas as consultants. The pine pr oject was terminated inconclusively in the late 1970 s, in spite of 15 years of international and national research effort. The pine fiasco was followed by an even larger plantation project based on Acacia mangium and backed by a loan from the Asian Development Bank. Now, after 15 years of effort, the Acacia planting programme is in serious trouble and may be terminated. In natural forests, enrichment planting was promoted through the 1960s and 1970s, and backed up by a Japanese research team in addition to considerable local effort. Yet enrichment planting was given up in about 1980.

\section{Tropical pines for pulp and paper}

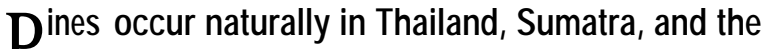
Philippines but, significantly, not in Malaysia. Pine species were first introduced for forestry experimentation in Malaysia in 1936 (Selvaraj and Muhammad 1980 ) and, in the 1950s, trials were established with Pinus caribaea, $P$. elliotii, $P$. insularis, $P$. massoniana, and P. merkusii mainly to test their suitability for rehabilitating of lands denuded by tin mining.

The FAO/UNDP project was launched as a pilot to demonstrate the feasibility of creating pine plantations to support a pulp and paper industry. Initially, research was not part of the project plan but the project staff quickly realized that much new research had to be done. Species and provenance trials were established in various parts of the country and Pinus caribaea var. hondurensis of the Caribbean region and P. merkusii of Indonesia were found to have the best growth rates among the contenders. However, it was P. caribaea var. hondurensis that got chosen, because seeds were readily available, originally from the Caribbean and later from Fiji.

There were some major problems with P. caribaea right from the start. Some $30 \%$ of the trees were foxtailed, and the foxtailed trees tended to be spindly and weak. As a result the young pine plantations always looked very uneven and unimpressive in comparison with the rubber and oil-palm plantations that Malaysians are used to (see Figure 1). Foxtailing could 
have been overcome by propagating foxtail-free genotypes and by establishing clonal seed orchards to produce improved seeds. However, P. caribaea failed to produce seeds under our climatic conditions. The FAO/UNDP staff established clonal seed orchards in the northernmost parts of the country, in Langkawi and Perlis, where there is pronounced wet/dry seasonality, and on various elevations on a mountain (Cunung Jerai). These orchards all failed to produce seeds. Furthermore, the pines were highly susceptible to termite attack.

When the FAO/UNDP project ended, we broke through the seed-production barrier simply by asking field staff if they had ever seen big cones in the pine plots in their districts. From their responses, three areas were identified, two of them on the coast and one on a mountain ridge. When we visited these areas we found that they had one environmental factor in common: steady wind conditions for carrying pollen in contrast to the relative stillness of the air in most parts of the country. Thus it was on a breezy mountain crest that we finally made our seed-production breakthrough ( $\mathrm{Ng}$ and Razali 1979), and we followed that up by establishing a progeny trial with the first harvest of locally-produced seeds.

As for the termite problem, this was initially solved by sprinkling a powdered organo-chlorine insecticide into every planting hole. The protection only lasted for a few years, after which termite attacks could occur at random, wiping out some areas and leaving others unscathed. Our entomologist began to make a study of termite ecology in the hope of developing biological means of control.

However, all research on pines ended when the pine-planting effort was given up. After 15 years, there had been no improvement at all in growth and form because the annual plantings were still made with unimproved imported seed. The local seed-production breakthrough had come too late to have an effect. No state was sufficiently impressed to allocate land for growing pines to sustain a modern pulp mill.

\section{Dipterocarps for enrichment of natural forests}

In the 1960s, the enrichment of logged natural forests through planting with dipterocarp seedlings was strongly promoted by the Forestry Department and nurseries were set up all over the country to raise dipterocarp seedlings. The biggest problems at that time were thought to be the sporadic and unpredictable nature of dipterocarp flowering and the non-storability of dipterocarp seeds. Therefore, to keep nurseries stocked, it was often necessary to collect wildings from the forest.

Research showed that dipterocarps became reproductive mostly at $20-30$ years $(\mathrm{Ng} 1966)$ and that the length of time between flower-opening and fruit maturity was mostly $2-5$ months, depending on the species ( $\mathrm{Ng}$ and Loh 1974). Other characteristics of dipterocarp reproductive and vegetative shoot growth were worked out and published by $\mathrm{Ng}$ (1981) while seed storage tests were carried out by Tang (1971). Under a British-funded project, Burgess carried out research on silviculture in the hill forests from 1967 to 1973 (Burgess 1975). Then a succession of Japanese scientists were attached to FRIM to work on the physiology of dipterocarp seeds and seedlings. Tamari (1976), Sasaki (1980, 1983), and Mori (1980) contributed greatly to our knowledge of seed physiology, while Momose (1978) made the first successful experiments in rooting cuttings of a range of species using leafy cuttings taken from juvenile plants.

By the late 1970s, we had enough knowledge to store recalcitrant dipterocarp seeds for 3-9 months, we had a strategy for collecting seeds from the sporadic flowering of dipterocarps that take place outside of mast years ( $\mathrm{Ng} \mathrm{1974),} \mathrm{and} \mathrm{we} \mathrm{knew} \mathrm{that} \mathrm{diptero-}$ carps could be propagated vegetatively with leafy cuttings from juvenile plants. We also had a good understanding of the dimorphic nature of the dipterocarp shoot system; in particular, that the side branches, although easily rooted, would retain their plagiotropic habit and were, therefore, not suitable for vegetative propagation. In principle, we could have, even with sporadic seed supplies, scaled up the production of dipterocarp planting stock by vegetative propagation from orthotropic seedling shoots.

However, the fact remained that enrichment planting was expensive and difficult. The high cost of planting was due to the fact that each worker could only carry up to 20 seedlings into the forest on a backpack. For those who learnt forestry in temperate countries, I have to explain that, in the humid tropics, there is no resting season for plants. Consequently, seedlings (especially large-leafed dipterocarp seedlings) transpire actively and are liable to desiccate in transplanting. Seedlings have to be transported and transplanted in their nursery bags of soil with as little disturbance as possible. On easy terrain, much of the carrying could be done by vehicles but, apart from a few showpieces, which conveyed a very misleading impression of the ease of enrichment planting the reality was that the forest lands were on very hilly 
terrain on which the only roads were those made for logging. While logging was in progress, the loggers would maintain the roads, but once the logging was over the roads would be eroded and rendered unusable within one year. The window of opportunity for planting was narrow and made even narrower by the fact that it was dangerous to drive up the slippery and eroding roads on rainy days, hence most of the planting took place in intermittent periods of dry weather. However, if dry weather persisted for more than a couple of days, the planted seedlings were likely to die from desiccation. There were also fears that the seedlings that suffered leader-shoot damage (dieback) would respond by producing multiple leaders and lose their timber value. These fears were found to be unjustified; indeed, the ability of dipterocarp seedlings to restore single-leader dominance was found to be virtually absolute ( $\mathrm{Ng} \mathrm{1976;} \mathrm{see} \mathrm{Figure} \mathrm{2a).}$

Our Japanese team experimented with chemical sprays to reduce transpiration from the leaves but were not successful. Eventually, Sasaki found a species eminently suited for enrichment planting. This was Shorea roxburghii (talura), which was found to have relatively long seed storage life for a Shorea and, most excitingly, it could be stored and transported as bare-rooted and de-leafed stumps and planted with little or no mortality, like teak. In practical terms this meant that planting stock could easily be carried into the forest and the stumps could survive many days without rain. The discovery of the superior propagative properties of Shorea roxburghii was to my mind the most important discovery by the Japanese team, but Sasaki was unable to complete the work before leaving at the end of his term and nobody else took up the work.

Research was also casting doubts on the need for enrichment planting. Enrichment planting in the hill forests had been initiated when little was known about the characteristics of hill forest regeneration. Hill forest research was carried out in 1967-1973 by Burgess and published in 1975. Burgess found that, because of the uneven distribution of trees, the steepness of terrain, the specificity of market demands, and the limitations of logging machinery, only $30-50 \%$ of the area of forests licensed for logging in the hills in that period were actually logged. Within the areas that were logged, the distribution of natural seedlings was uneven due to the uneven distribution of seedbearing trees.

Consequently, enrichment planting would only make sense if the workers doing the planting were guided by their own observations on the ground.
However, enrichment planting was not carried out like that. Decisions were made in offices and, once it was decided to plant a forest compartment, planting would bedone at fixed spacings in parallel lines with no regard for the presence of natural regeneration. In fact, natural regeneration would be slashed to make way for planting. Tang and Wadley (1976) characterized the operation as line planting rather than enrichment.

Burgess' work also cast doubt on the silvicultural practice of poisoning the residual trees left after the marketable trees had been logged. In theory, this had to be done to free regeneration from competition. In an experiment comparing the effect of killing residual trees 6 inches $(15 \mathrm{~cm})$ diameter and above versus understorey cutting of vegetation of 6 inches diameter and below, Burgess (1975) found the latter to be far more effective in stimulating height growth in the dipterocarp seedlings (mean of $13.6 \mathrm{ft}$ in 2 years versus $7.2 \mathrm{ft}$ ). This showed that competition was much greater from the understorey than from residual big trees. In hindsight, this was to be expected. An umbrella shades you only if it is immediately above your head, not if it is $20 \mathrm{~m}$ overhead.

By 1981, we had also begun to appreciate that the emergent trees of tropical rainforests undergo an architectural metamorphosis as they reach canopy level, during which their crowns become almost monolayered, allowing much more light to penetrate than during their juvenile stages when their crowns have multi-layered foliage ( $\mathrm{Ng} 1981$, Hallé and $\mathrm{Ng}$ 1981; see Figure 2b). This lent further support to Burgess' discovery that understorey vegetation has a much stronger suppressive effect on regeneration than the upper canopy.

We expected the Forestry Department to revise the system of dipterocarp planting but, instead, dipterocarp planting was given up altogether. A survey by Tang and Wadley (1976) had indicated that a lot of the planting may have been unnecessary, and that, in any case, the mortality rate of planted seedlings was averaging $50 \%$. By 1980 , enrichment planting was given up throughout the country. The planners in headquarters were preparing for a new mission. They had concluded that dipterocarp regeneration would be too slow to meet the projected need for timber in the mid-1990s. It was in anticipation of this timber shortage that the Forestry Department decided to launch its Compensatory Plantations Project, to compensate for the slow regeneration of natural forests.

The scene of action in enrichment planting moved to Indonesia, where W. Smits took up the 
cause and devised a hydroponic method for rooting leafy cuttings (see review by Kantarli 1993). The ASEAN Forest Tree Seed Centre, set up Thailand in 1981, made vegetative propagation even easier with the development of improved potting composts (Kijkar 1991).

\section{Compensatory plantations for sawn timber: Eucalyptus camaldulensis and Acacia mangium}

In the initial stages of planning of the Compensatory Plantation Project, five candidate species were proposed which were thought capable of producing sawn timber (trees of minimum diameter of $45 \mathrm{~cm}$ at breast height) in 15 years. These were Pinus caribaea, Muesopsis emenii, Gmelina arborea, Eucalyptus deglupta, and Albizia falcataria. Pinus caribaea and Gmelina arborea were quickly eliminated because we already knew that they were very site-sensitive. Maesopsis was eliminated because timber tests showed that the wood fibres were woolly, making the timber difficult to saw and plane. Euculyptus deglupta was eliminated because the trees were found to suffer greatly from heartrot.

Only Albizia falcataria remained and, to this, two new candidate species, Eucalyptus camaldulensis and Acacia mangium, were added. Interest in Albizia falcataria faded when a stand established with seeds purchased from the Philippines turned out to have excessively poor form. E. camaldulensis had been tried in small trials and had shown good initial growth rates of about $3 \mathrm{~m}$ height per annum. Seeds were obtained from Australia and several thousand hectares were planted between 1981 and 1984. Initial height growth was very rapid, but the trees were spindly, cast no shade, and allowed Imperata grass to cover the ground unchecked. Then, in 1984, during a prolonged period of rainy weather, a leaf fungus disease caused massive defoliation and wiped out the plantations.

Looking back through FRIM's records after this disaster, I found that over 27 species of Eucalyptus, including $E$. camaldalensis, had been planted in over 80 experimental plots in its grounds between 1939 and 1976 (Selvaraj and Muhammad 1980). All of them had been abandoned after, at most, 7 years of measurements, with nothing published and with no surviving specimens. We now have reason to suspect, from the E. camaldulensis disaster of 1984, that they were weakened and wiped out by leaf fungus disease (Figure 3). As we all know, it is not the normal practice to publicize failures. Even the disaster of 1984 has not been written about and published, so I expect that when all has been forgotten, somebody else will try to establish eucalyptus plantations again in the lowlands of Malaysia.

Acacia mangium had been reported to have grown exceedingly well in Sabah when planted in firebreaks in pine plantations. The first trial in Peninsular Malaysia was established under my supervision in a half-acre experiment on a very degraded site in Kemasul, using seeds from Sabah. The site had originally been slashed and burnt for growing pines but the pine seeds imported that year had failed to germinate. The site was abandoned until the next year when it was slashed and burnt again before planting with pines. By then the site was heavily eroded and leached, and the pine seedlings were unable to get established. When we took over the site, it looked as if no trees could ever grow there again. To our enormous surprise, the A. mangium grew rapidly, straight and tall. We had found our miracle tree, or so it seemed.

With encouragement (and a big loan) from the Asian Development Bank, mangium seeds were imported from Australia and planted on a big scale. Having learnt from the pine experience, the planting programme was carried out meticulously through contractors. Areas were slashed and burnt and seedlings were planted as soon as the ashes had cooled. Then a very strange thing happened. All the trees developed multiple trunks right from the base. This had never happened before, not on our original highly degraded trial site, not on the firebreaks in Sabah, and not to individual trees in gardens. We thought we had a genetic problem. Provenance trials were carried out using seeds from different parts of Australia, but all the provenances had the same problem. How was it that the original plantings did not reveal this problem?

The difference was in site preparation. Wherever the plants were established on newly burnt sites, they developed multiple leaders. Prof. Josef Racz, then working at FRIM as a member of a GTZ project, did some work which indicated that the multiple leaders might be a response to the increased level of potash produced in burning. It is amazing that the architecture of a tree can be so drastically altered by the nutrient status of the soil. Because of the multiple shoots, the Forest Department introduced the procedure of 'singling', which involved selecting one shoot per tree and chopping off all the rest.

Then other problems began to surface. After 10 years, there were strong indications from the original 
halt-acre plot that growth would tend to cease just short of the target of $45 \mathrm{~cm}$ diameter. Most serious of all was the susceptibility of mangium to heartrot. This problem was already known in Sabah, but was regarded as an inconvenience rather than a real impediment. Then, in 1993, reports to FAO (where I was then working) from trials in Bangladesh and Vietnam indicated that extent of heartrot in mangium was disastrous. Surveys by FRIM confirmed that the problem could not be ignored. The first reaction was to call in the pathologists, but heartrot is not really a disease problem. Figures 4a-e illustrate this story.

Our understanding of the nature of wood is that trees fall into three classes with respect to their woodaccumulation strategy.

(1) Trees like teak (Tectona grandis) and chengal (Neobalanocarpus heimii) deposit preservative compounds that chemically protect their heartwood. Such trees accumulate wood for as long as the protection lasts but, when they get old, the oldest wood may break down. For example we know from durability tests that chengal timber lasts about 100 years when used under exposed conditions, which means that a big old tree is likely to develop rot in its core where the wood is older than 100 years.

(2) Trees like rubber Hevea brasiliensis and jelutong Dyera costulata keep all their wood alive. Because living tissues do not rot (only dead and unpreserved tissues rot; $\mathrm{Ng}$ 1986), such trees character istically have sound wood throughout and even load up their wood cells with starch grains.

(3) Trees that do neither and which are thereby susceptible to heartrot at an early age. Mangium's early susceptibility to rot suggests that it belongs to the third class.

Please see Figures $5 \mathrm{a}$ to $5 \mathrm{e}$.

A. mangium remains a great discovery and a wonder tree for reclaiming Imperata and other kinds of degraded land, and as a source of small-diameter wood. It is for sawn timber that its potential has been misjudged.

\section{Why was research unable to influence the course of events?}

Scientists are often accused of doing research unreSlated to user-needs or demands, and this is given as the reason for the poor interaction between scientists and end-users of research. This review indicates that the reasons are much more complicated.
For example, we found that users do not like bad news. In the case of enrichment planting the Forest Department expected a positive- assessment from Tang and Wadley, and was hostile when the assessment was negative. The bad news that mangium suffers from heartrot was even more badly received, as if the scientists were responsible for the rot. Burgess' finding that the long-established-silvicultural practice of girdling residual trees was not as effective as understorey control was simply ignored.

The good news, such as the breakthrough in pine seed production and the development of Shorea roxburghii for bare-root planting, came too late to have an effect. It is as if project management is a race against time; as problems arise and doubts accumulate, project optimism is worn down to a point at which even good news coming towards the end cannot prevent the death of the project. The good news has to be generated in a continuous stream, and starting early.

I think the real problem at the interface between research and application is that research is rarely able to provide support in the form of a continuous stream of confidence-building discoveries. In a review like this, which covers 30 years, I can fill 10 pages with accounts of discoveries. But if I had to write an annual report for each year, I would have had a lot of trouble. Research was so slow to produce useful results that some years there was almost nothing of importance to report. As a manager of scientists at a national level, this troubled me greatly and, in my present international position, it continues to trouble me because we promote research in developing countries on the premise that research is an efficient problem-solving mechanism that countries cannot afford not to have. But, if this premise is true, why is it not more self-evident?

Various authors have examined why Third World Science is not more self-sustaining (e.g., Gaillard 1991) and attributed it to a variety of factors, including poor pay, unstable organizations, and lack of training. None of these factors applied in Malaysia except the lack of proper training. My observation as a manager of scientists was that all newly-recruited scientists began with enthusiasm but the majority failed to find inspiration and motivation, and soon settled into a dull routine. They failed to find the path of discovery which alone can bring life into research. I think all successful scientists know that discovery is an art, but scientists get little or no training in this art. Instead, they get trained in 'research methodology' which is only remotely related to the art of discovery. The 


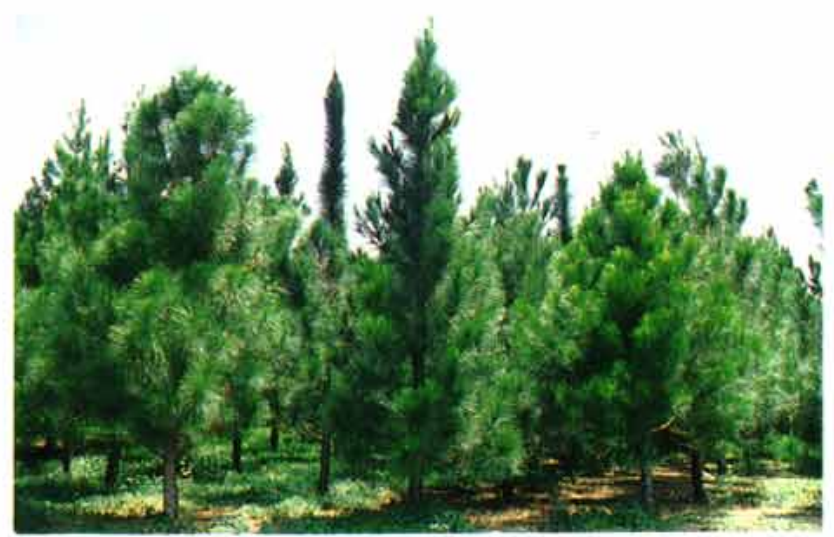

Figure 1. A stand of Pinus caribaea showing the great variation in form and the extent of foxtailing.

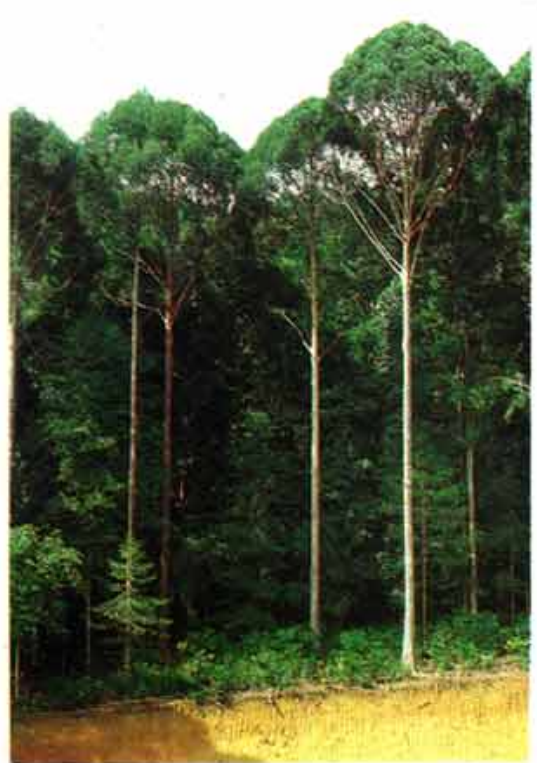

Figure $2 a$. A profile in which the juvenile trees have characteristically oblong crowns due to single-leader dominance, lateral orientation of branches, and multilayered foliage. At the mature canopy level, the crown shape becomes rounded because the shoots are more erect and coequal, follage becomes monolayered, and the juvenile lateral branches are shed to reveal the clear bole.
Figure 2. Metamorphosis in dipterocarp trees.

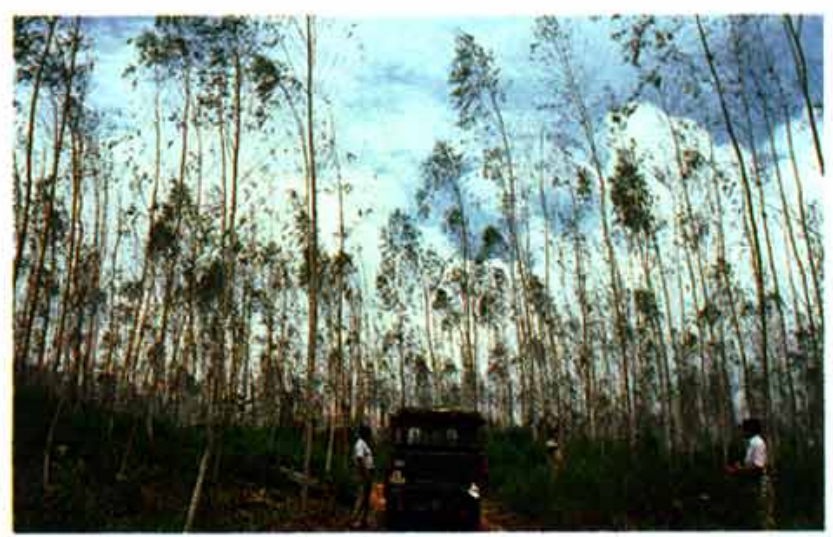

Figure 3. The Eucalyptus camaldulensis disaster in Kemasul, March 1984 , when leaf fungus wiped out the whole plantation. 
Figure 4. The Acacia mangium saga.

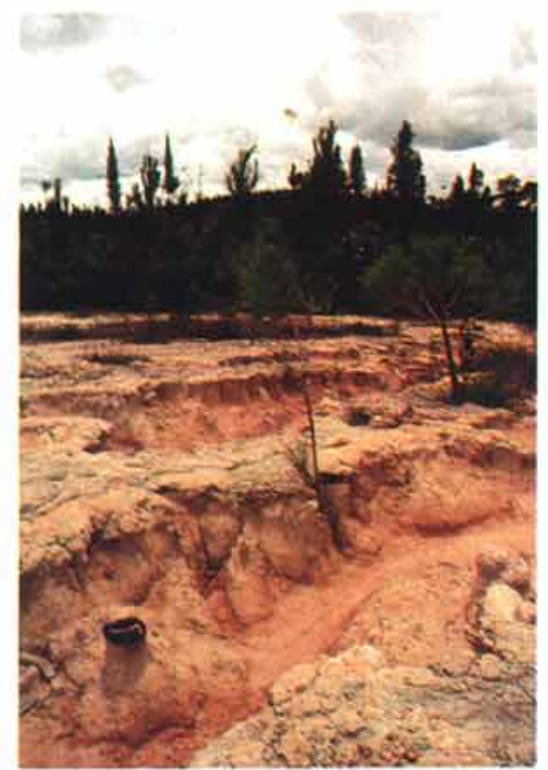

Figure $4 a$. The degraded site in which the first trial was established.

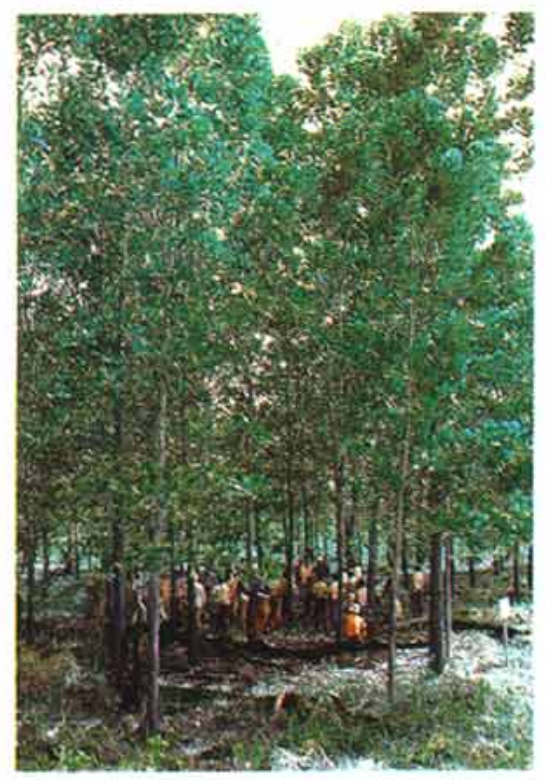

Figure $4 c$. The result after 49 months.

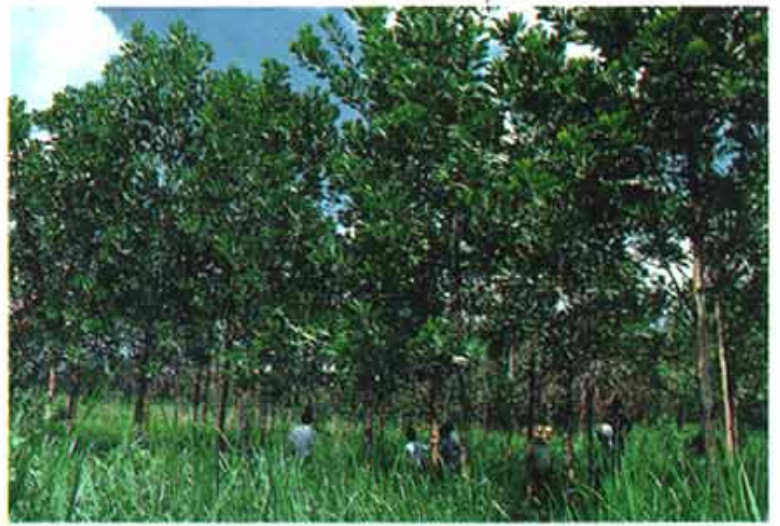

Figure $4 b$. The result after 25 months.

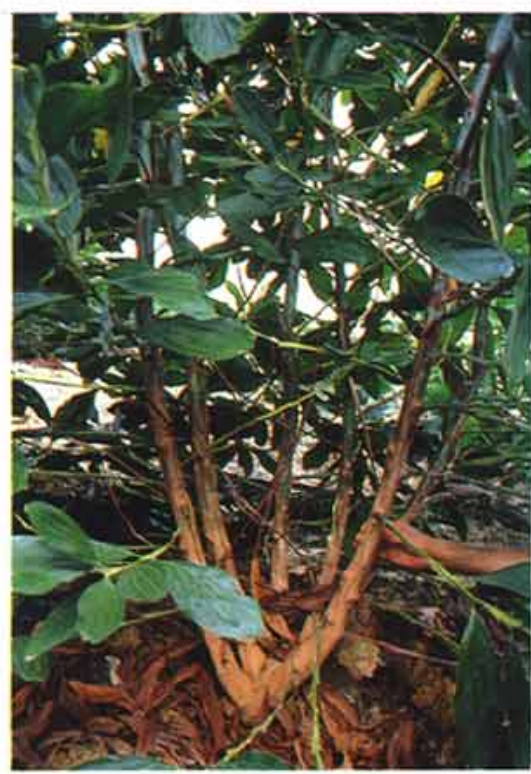

Figures $4 d$. The development of multiple shoots on sites that had been properly slashed and bumt prior to planting.

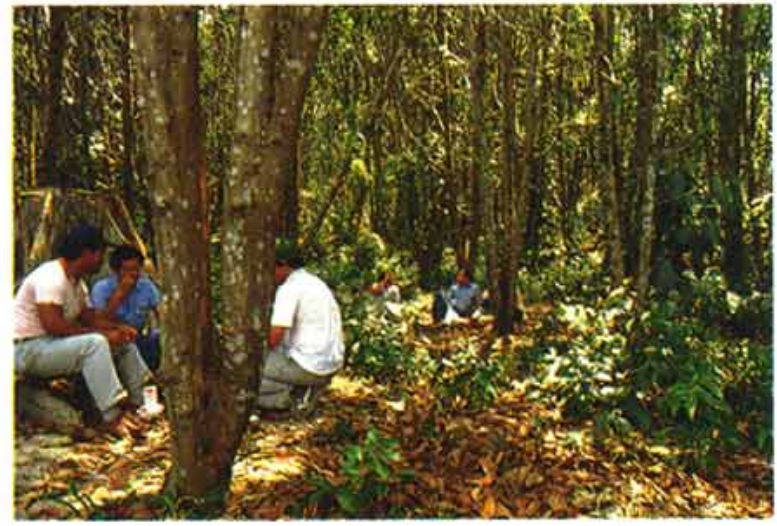

Figures $4 e$. The development of multiple shoots on sites that had been properly slashed and burnt prior to planting. 
Figure 5. The evidence that wood can be accumulated as living tissue

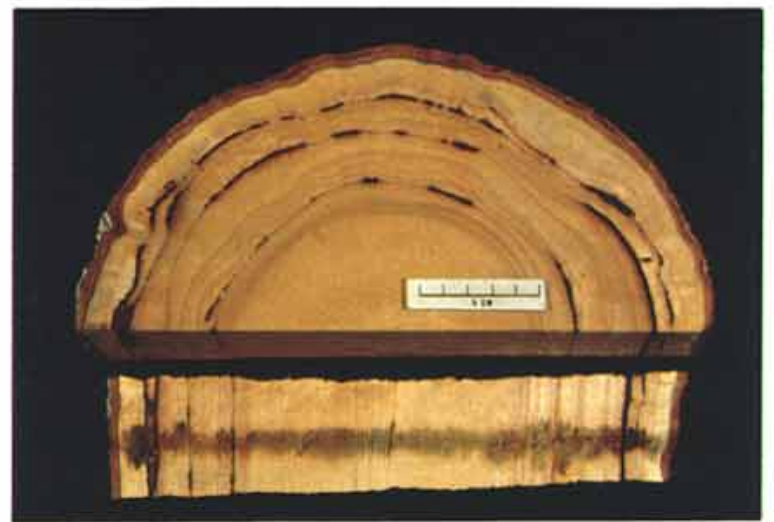

Figure 5a. Sections of a badly tapped nubber (Hevea brasiliensis) tree, in which the history of injury is recorded in the darkcoloured concentric lines of infection. However, the wood has responded by containing the infection to the points of actual injury. The lower section shows the effect of iodine applied as a band across the wood, staining the abundant starch grains in the wood cells.
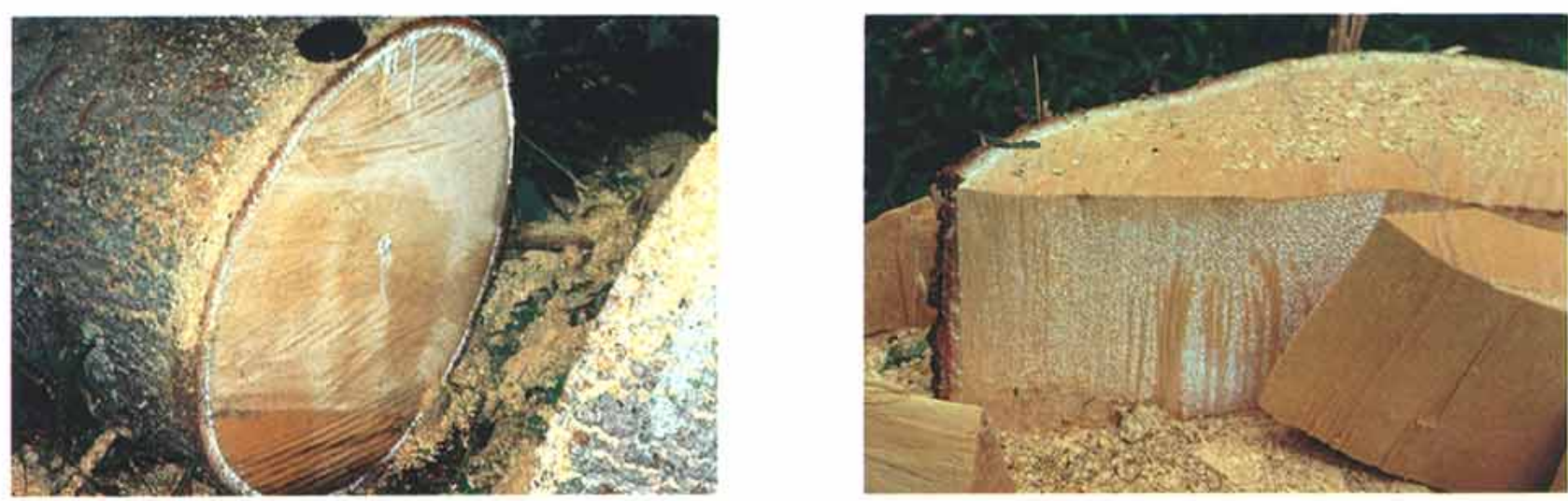

Figures $5 b$ and $5 c$. Transverse (b) and radial (c) surfaces of freshly-felled jelutong (Dyera costulata) with latex oozing from the bark, pith, and rays. The Rubber Research Institute of Malaysia has found that latex is a suspension of latex chemicals, mitochondria, ribosomes, and other sub-cellular organelles.

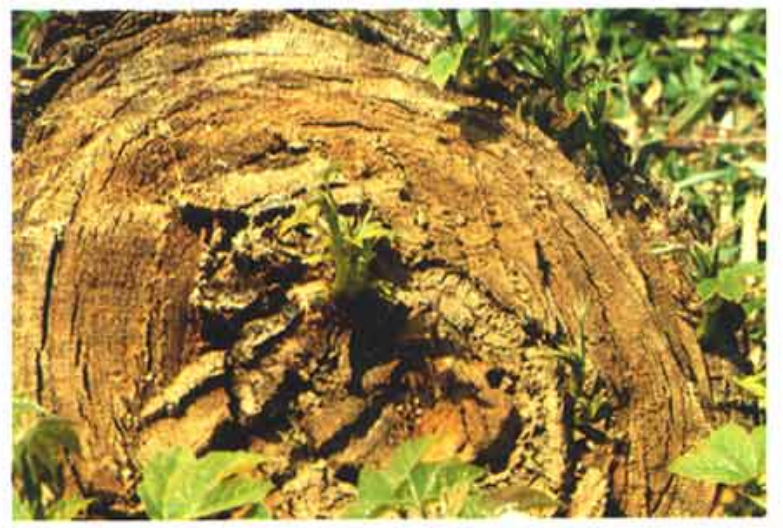

Figure $5 d$. The regeneration of shoots from the centre of a stump of Cochleospermum vitfollium.

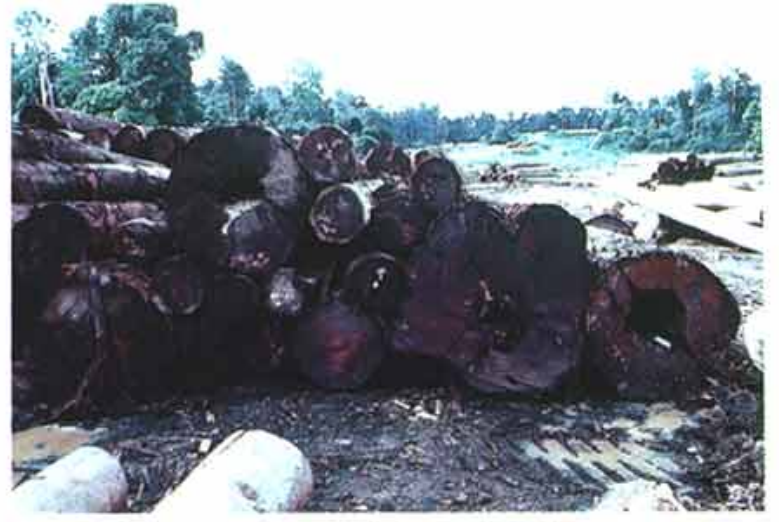

Figure 5e. Logs of chengal (Neobalanocarpus heimii). The large logs are hollow while the small logs are solid, indicating is that large logs are much older than 100 years, which is the known limit of durability of chengal timber in usage under exposed conditions. 
difference between the art of discovery and the 'research methodology' being taught to scientists is reflected in the following statements.

The British Nobel prizewinner Peter Medawar, wrote in 1984:

"There is ... no such thing as 'the' scientific method. A scientist uses a very great variety of exploratory strategems, and although a scientist has... a certain way of going about things that is more likely to bring success than the gropings of an amateur, he uses no procedure of discovery that can be logically scripted."

Contrast this with the following from the IUFRO publication 'FORSTAT, Module 1: Scientific Method and Problem Solving' (Anon. 1992), which says:

"Scientific method is the only safe way of developing planned experience. It involves the careful testing of statements which have been made in advance of the collection of any measurements or information. It also involves the use of statistical methods which are capable of detecting whether events have occurred by chance or by design."

Discoverors use any method that may produce results. Methodologists insist that there is a 'right' method that we must follow. If you have been brainwashed in a methodology course you will never do an experiment without large samples, controls, replicates, and tests of significance.

Consider this experiment by the French Nobel prizewinner Louis Pasteur in 1885. Pasteur, having successfully developed a vaccine against chicken cholera, felt confident that using the same approach, he could develop a vaccine against rabies. He went ahead and developed the vaccine. But how do you test such a vaccine? You cannot deliberately expose people to rabies to see whether the vaccine will work. You cannot accumulate a large sample of victims before you carry out an experiment in which you vaccinate some victims and keep others untreated as experimental controls. What Pasteur did was to use his vaccine on a boy who had just been bitten by a rabid dog. There was nothing to lose, because nobody had ever survived after being infected with rabies. The boy recovered after being treated and Pasteur became a hero. Even the skeptics were convinced after the next victim was saved, and then the next.

You may say that Pasteur got away with an experiment using a sample of one, because he did it in 1885. How about this late 20th Century discovery by the American Nobel prizewinner Kary Mullis, of the polymerase chain reaction. The discovery was made in his mind then confirmed by experiment. In his own words (1991):

"Months passed as I prepared for my first experiment to verify whether the PCR would work. I had to make many educated guesses about what buffer solution to use, what the relative and absolute concentrations of the reactants should be, how much to heat and cool the mixtures, how long the mixtures should run and so on."

"When everything was ready, I ran my favorite kind of experiment: one involving a single test tube and producing a yes or no answer. The answer was yes."

In going through the history of discovery, and even among the examples in this review, it is evident that discoveries are made in many different ways, e.g., by questioning (the pine seed production breakthrough), screening (the discovery that Shorea roxburghii is suited for bare-root planting ), comparative experimentation (the discovery that understorey control is more effective than overstorey control in stimulating regeneration), non-comparative experimentation (the confirmation of Acacia mangium as a miracle tree in a half-acre unreplicated trial), observations on single specimens (shoot regeneration from the woody core of a stump of Cochleospermum), observations on diverse specimens but not all at the same time (the dimorphic nature of the dipterocarp shoot system), by analogy (deducing the nature of mangium wood by analogy with other woods) and, most importantly, by chance. But as Pasteur has remarked, chance favours the prepared mind.

The methodologies promoted in courses and books on experimental design are preoccupied with the use of statistics to establish the validity of comparisons. A large part of research has to do with comparisons, e.g., to determine which variety, species, or clone grows best, or which level of fertilization, light, temperature, etc. is optimal for plant growth. The development of statistical techniques to enable us to differentiate between true differences and those that may have been thrown up by chance has contributed to the advancement of science, particularly where the differences are small, overlapping, and variable.

It cannot be denied that methods of comparison are methods of discovery. But they are not the most efficient for all purposes. The requirement for large samples, replicates, and controls inevitably increases the expense and logistics of experiments. Having 
found out that one result is significantly different from another, we still have to figure out why, otherwise the discovery is incomplete. For example, the discovery that one treatment produces $30 \%$ rooting in cuttings compared to another which produces $20 \%$, and that the difference is highly significant, does not really tell us what is happening. Why did the other cuttings not root? To ask why, and to keep that question in the mind until it is solved, is part of the preparation of the mind for discovery. Until then, we only have data or even highly-processed data, but only a little knowledge. The big discovery is yet to be made!

The discoveries that light up the scientific landscape from time to time, like lights being switched on in the dark, tend to be qualitative. Yes or No. This vaccine works! The PCR works! Here are big pine cones! Active latex means living tissue! The rate of growth on this kind of site is extraordinary! A discovery-efficient strategy must involve all the tools available, quantitative and qualitative, as well as common sense and innovative thinking. To find out which species can be bare-rooted, rapid and simple screening is a lot more efficient than a factorial experiment. To understand plants as living systems, the messages conveyed by the colour, orientation, life span, and surface area of leaves may be far more informative than the measurements of stem height and diameter that we routinely make. In collecting data, we must keep in mind that the answer may not be in the data at all, that logic has never been a sure guide to discovery, and that no method is good in itself. It is the result that tells whether the method was good. How often have we sat through scientific meetings listening to long presentations of method, only to be disappointed by the results at the end. If the results were disappointing, we can only conclude that the method was bad for that particular investigation.

There is a story that a team of well-funded scientists from a large research institute was assigned to study how to increase the productivity of catfish reared in ponds. The problem was that the catfish population would build up quickly and then decline inexplicably. The scientists drew up a comprehensive scheme of data collection in which the water quality would be carefully monitored, together with the feed, the fish population, the weather, and so on. With computer-aided statistical packages, they hoped to find the correlations and the answer. They failed. A lone scientist who was not a member of the team found the answer by observing that the population of catfish drops because sooner or later a water snake takes up residence in the pond and gobbles up the young catfish as they emerge from their mudholes. No mathematical logic, no factorial experiment, no plan or budget, could ever have led to such a discovery.

This review leads me to the following conclusions:

- Discoveries, and the methods behind them, can only be evaluated fairly after the discoveries are made.

- Because we cannot predict the nature of individual discoveries, a high rate of discovery is needed to ensure that big discoveries will occur frequently, that long-term experiments will be protected and sustained by short-term experiments, that there will be positive discoveries to counterbalance negative ones, and that we can offer clients alternative solutions instead of confrontational ones.

- To generate a high volume of discoveries, we need a research strategy which generates discoveries efficiently.

The generation of evidence through planned experiment is only one part of the discovery process. A scientist must also be able to detect, recognize, and interpret evidence no matter how such evidence may present itself. The preparation of the mind for such detective work is the most deficient part in the training of scientists. Without such preparation, scientists are likely to go through the motions of experiment, following textbook formulae and thinking that this is what research is all about.

\section{An 80:20 proposition}

$T_{0}^{0}$ 0 be realistic, some $80 \%$ of our research time has to be spent on formal research that is plannable, quantifiable, budgetable, announceable, and justifiable a priori (before the research is done) by approved methodology. This is what we need to do to get money to keep our institutions alive, buy equipment, pay staff, and fill up horizontal gaps in knowledge.

Some $20 \%$ of our research time may be all that is needed for informal, unbudgeted exploration, justified a posteriori by discoveries. This is needed to keep the spirit of science alive in our institutions and to build knowledge vertically into new levels.

The 80:20 proposition is neither new nor radical. Many experienced research managers, both in the public and private sectors, apply this quietly. Where research managers do not understand or recognize the need, it is for the scientists individually to find the extra time for it, making it a 100:20 proposition. I am sure we all became scientists in order to take part in the excitement of discovery and, until we do, it is very 
difficult for us to maintain our credibility, effectiveness, and authority as scientific problem-solvers.

In this review, I have not touched upon the problems of communication between scientists and project managers, nor on the way in which managers make decisions. We can put the blame on poor communications and we can put the blame on poor management. But, often, I found that we could not communicate with confidence and authority because our research was not sufficiently confident and authoritative. Nor were we able to produce timely and wellresearched alternatives that could have enabled managers to make better decisions.

\section{Acknowledgments}

am grateful to Thomas Enters for critical comments on this paper.

\section{References}

Anon. 1992. FORSTAT Module 1: Scientific Method and Problem Solving. IUFRO, Vienna.

Burgess, P.F. 1975. Silviculture in the Hill Forests of the Malay Peninsula. FRIM Res. Pamphlet 66. Kepong, Malaysia.

Gaillard, J. 1991. Scientists in the Third World. University Press of Kentucky, Lexington, KY, USA.

Halle, Fi; Ng, F.S.P. 1981. Crown construction in mature dipterocarp trees. Malays. Forester 44: 222-233.

Kantarli, M. 1993. Vegetative propagation of dipterocarps by cuttings in ASEAN Region. AFTSC, Muak Lek, Thailand.

Kijkar, S. 1991. Coconut husk as a potting medium. AFTSC, Muak Lek, Thailand.

Medawar, P. 1984. The limits of science. Oxford Univ. Press.

Momose, Y. 1978. Vegetative propagation of Malaysian trees. Malays. Forester 41: 219-223.

Mori, T. 1980. Physiological studies on some dipterocarp and rattan species of Peninsular Malaysia as a basis for artificial regeneration. FRIM Res. Pamphlet 78. Kepong, Malaysia.

Mullis, K.B. 1991. The unusual origin of the polymerase chain reaction. Pages 104-111 in Sci. Am. Special Issue: Science in the 20th Century.

$\mathrm{Ng}$, F.S.P. 1966. Age at first flowering in dipterocarps. Malays. Forester 28: 289-306.

$\mathrm{Ng}$, F.S.P. 1974. Seeds for reforestation: a strategy for sustained supply of indigenous species. Malays. Forester 37: 271-277
$\mathrm{Ng}$, F.S.P. 1976. Responses to leader-shoot injury in Shorea platyclados. Malays. Forester 39: 91-100.

$\mathrm{Ng}$, F.S.P. 1980. Tree improvement and seed procurement activities in Malaysia. Pages 73-79 in Proc. SE Asian Tree Improvement and Seed Procurement Cooperative Programme. Royal Forest Department, Bangkok.

$\mathrm{Ng}$, F.S.P. 1981. Vegetative and reproductive phenology of dipterocarps. Malays. Forester 44: 197-221.

$\mathrm{Ng}$, F.S.P. 1984. Plant phenology in the humid tropics. FRIM Res. Pamphlet 88. Kepong, Malaysia.

$\mathrm{Ng}$, F.S.P. 1985. Identification and conservation of genetic resources. Pages 63-75 in Burley, J.; Stewart, J.L., eds. Increasing productivity of multpurpose species IUFRO, Vienna.

$\mathrm{Ng}$, F.S.P. 1986. Tropical sapwood trees. Pages 61-67 in Proc. Intl. Symp. on the Tree. Institut de Botanique, Montpellier, France.

$\mathrm{Ng}$, F.S.P. 1991. Manual of forest fruits seeds and seedlings. Vol 1. FRIM, Kepong, Malaysia.

$\mathrm{Ng}$, F.S.P. 1992. Manual of forest fruits seeds and seedlings. Vol 2. FRIM, Kepong, Malaysia.

$\mathrm{Ng}$, F.S.P.; Loh, H.S. 1974. Flowering to fruiting periods of Malaysian trees. Malays. Forester 37:127-132.

Ng, F.S.P.; Mat Asri bin Ngah Sanah. 1991. Germination and Seedling Records. FRIM Res. Pamphlet 108. Kepong, Malaysia.

$\mathrm{Ng}$, F.S.P.; Razali Husin. 1979. First harvest of pine seeds in Peninsular Malaysia. Malays. Forester 42: 73.

Sasaki, S. 1980. Storage and seed germination of dipterocarp seeds. Malays. Forester 43: 290-308.

Sasaki S. 1983. Physiological studies on seedlings of dipterocarps with particular reference to Shorea ovalis and Shorea talura FRIM Res. Pamphlet 92. Kepong, Malaysia.

Selvaraj, P.; Muhammad bin Abu Bakar. 1980. A checklist of plantation trials in Peninsular Malaysia. FRIM Res. Pamphlet 79. Kepong, Malaysia.

Tamari, C. 1976. Phenology and seed storage trials of dipterocarps. FRIM Res. Pamphlet 69. Kepong Malaysia.

Tang, H.T. 1971. Preliminary tests on the storage and collection of some Shorea species seeds. Malays. Forester 34: 84-98.

Tang, H.T.; Wadley, H. 1976. Report on the survival and development survey of areas reforested by line planting in Selangor. FRIM Res. Pamphlet 67. Kepong, Malaysia. 